\title{
触 New Disease Reports \\ First report of Verticillium wilt caused by Verticillium dahliae on mango in Israel
}

\author{
A.G. Levin ${ }^{1}$, O. Erlich ${ }^{2}$, S. Lebiush ${ }^{2}$, M. Hazanovsky ${ }^{2}$ and L. Tsror $\left[\right.$ Lahkim] ${ }^{2 *}$ \\ ${ }^{1}$ Northern $R \& D$, South Industrial Zone, Kiryat Shmona, 11016, Israel; ${ }^{2}$ Department of Plant Pathology, ARO, Gilat Research \\ Center, MP Negev, 85250, Israel
}

*E-mail: tsror@agri.gov.il

Received: 05 Mar 2014. Published: 14 Apr 2014. Keywords: Mangifera indica, fungal plant disease

\begin{abstract}
Verticillium wilt caused by the fungal pathogen Verticillium dahliae is considered one of the most important diseases in a wide range of vegetables, field, ornamental and tree crops (Schnathorst, 1981). The disease has been reported previously on mango (Mangifera indica) in southern Spain (Baeza-Montañez et al., 2010). In 2008, first symptoms of Verticillium wilt were observed in several mango trees (cvs. Keitt and Shelly), in a grove located in the Sea of Galilee area, grown under organic management in soil previously cropped with avocado which was infected with $V$. dahliae. Since the winter of 2009 , the disease has spread rapidly in the grove amongst the different cultivars, reaching an incidence of $20 \%$ diseased or dead trees (18 months after the first symptoms) and has also been detected in adjacent groves in the same region. The symptoms observed included wilt and chlorosis, branch dieback on one side of the shoot, drying leaves remaining attached to branches and vascular discoloration (Fig. 1). Verticillium dahliae was isolated from segments of the vascular bundles taken from surface-sterilised symptom-bearing branches (from both cultivars) and placed on potato dextrose agar (PDA). After incubating the plates for five days in the dark at $25^{\circ} \mathrm{C}$, typical $\mathrm{V}$. dahliae colonies were observed.
\end{abstract}

Isolates were initially identified on the basis of conidiophore morphology and microsclerotia production. This identification was confirmed by PCR using the $V$. dahliae-specific primers (Vd-F: 5, CCGGTCCATCAGTCTCTCTG - 3, Vd-R: 5' 5' ACTCCGATGCGAGCTGTAAC - 3'; product size $300 \mathrm{bp}$ ) designed from the sequence reported in Nazar et al. (1991) and Robb et al. (1993). Isolates were assigned to vegetative compatibility groups using the international set of testers (Joaquim \& Rowe, 1990), and all tested isolates belonged to VCG4B. In addition, $V$. dahliae was successfully detected in soil samples (0.6-0.8 microsclerotia/g soil) taken from the infested grove using RT-PCR analysis with $V$. dahliae-specific primers Vd-F929-947, Vd-R1076-1094 and probe Vdhrc FAM (Bilodeau et al., 2012). To our knowledge, this is the first report of Verticillium wilt on mango in Israel. The disease continues to severely damage mango groves in the reported area for several reasons such as heavy and alkaline soils and intensive irrigation, which enhances the establishment and development of $V$. dahliae.

\section{References}

Baeza-Montañez L, Gómez-Cabrera R, García-Pedrajas MD, 2010. First report of Verticillium wilt caused by Verticillium dahliae on mango trees (Mangifera indica) in southern Spain. Plant Disease 94, 380. http://dx.doi.org/10.1094/PDIS-94-3-0380C

Bilodeau GJ, Koike ST, Uribe P, Martin FN, 2012. Development of an assay for rapid detection and quantification of Verticillium dahliae in soil. Phytopathology 102, 331-343.

http://dx.doi.org/10.1094/PHYTO-05-11-0130

Joaquim TR, Rowe RC, 1990. Reassessment of vegetative compatibility relationships among strains of Verticillium dahliae using nitrate nonutilizing mutant. Phytopathology 80, 1160-1166. http://dx.doi.org/10.1094/Phyto-80-1160

Nazar RN, Hu X, Schmidt J, Culham D, Robb J, 1991. Potential use of PCR-amplified ribosomal intergenic sequences in the detection and differentiation of Verticillium wilt pathogens. Physiological and Molecular Plant Pathology 39, 1-11. http://dx.doi.org/10.1016/0885-5765(91)90027-F Robb J, Moukhamedov R, Hu X, Platt H, Nazar RN, 1993. Putative subgroups of Verticillium albo-atrum distinguishable by PCR-based assays. Physiological and Molecular Plant Pathology 43, 423-436.

http://dx.doi.org/10.1006/pmpp.1993.1070

Schnathorst WC, 1981. Life cycle and epidemiology of Verticillium. In: Mace ME, Bell AA, Beckman CH, eds. Fungal wilt diseases of plants. New York: Academic Press New York, 81-111.

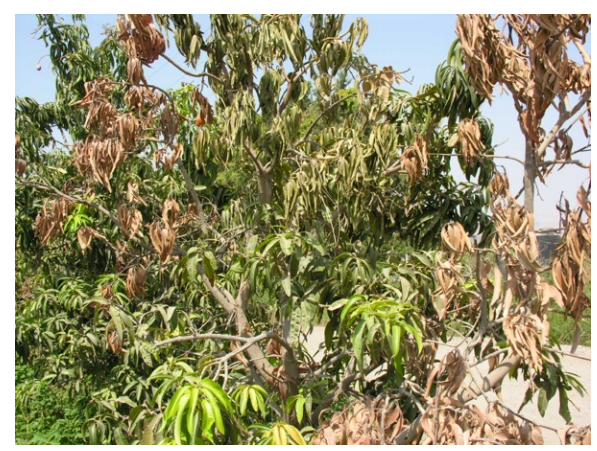

Figure 1

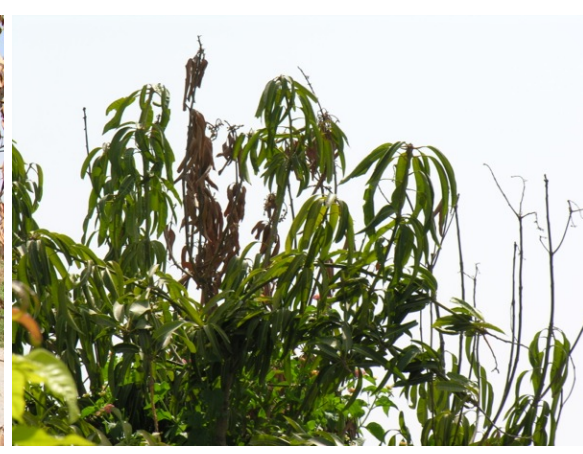

Figure 2

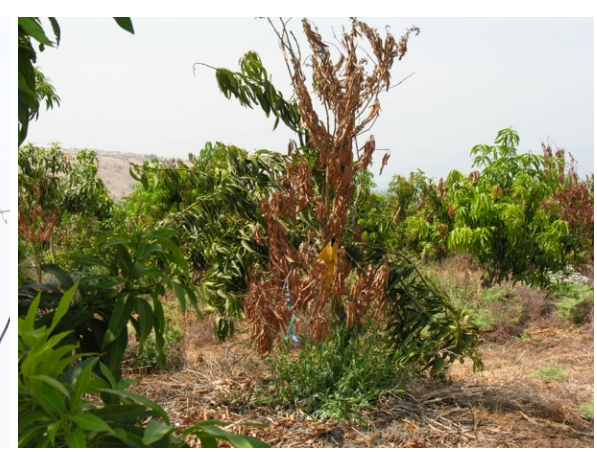

Figure 3

To cite this report: Levin AG, Erlich O, Lebiush S, Hazanovsky M, Tsror [Lahkim] L, 2014. First report of Verticillium wilt caused by Verticillium dahliae on mango in Israel. New Disease Reports 29, 14. http://dx.doi.org/10.5197/j.2044-0588.2014.029.014 